Digitalizacja archiwalnych numerów czasopisma naukowego Analecta Cracoviensia 1-24 (1969-1992)

i ich publikacja w otwartym dostępie - zadanie finansowane w ramach umowy 672/P-DUN/2017 ze środków

Ministra Nauki i Szkolnictwa Wyższego przeznaczonych na działalność upowszechniającą naukę

\title{
ŚWIECCY W SŁUŻBIE SPOŁECZEŃSTWU I ŚWIATU W SWIETLE ADHORTACJI „CHRISTIFIDELES LAICI”
}

VII synod biskupów głosi, że Kościół Chrystusowy, za pośrednictwem świeckich, ma być obecny w świecie — w różnych dziedzinach jego życia i działania — jako znak i źródło nadziei i miłości. Dzięki świeckim winna dotrzeć do świata, co więcej - do każdego człowieka, następująca prawda: „Człowiek jest kochany przez Boga. Oto proste, a jakże przejmujące orędzie, które Kościół jest winien człowiekowi. Każdy chrześcijanin może i musi słowem oraz życiem głosić: Bóg cię kocha, Chrystus przyszedł dla Ciebie, Chrystus dla Ciebie jest Drogą i Prawdą i Życiem"1.

Swieccy, powołani do świata, do jego odnowy, są zobowiązani służyć człowiekowi i społeczeństwu w ten sposób, że mają świat przekształcać, wprowadzając tam Chrystusa - żywą Ewangelię. Ta sprawa stanowi przewodnią ideę posynodalnej adhortacji apostolskiej Christifideles laici i ją zamierza ukazać niniejszy artykuł.

\section{Powołanie świeckich}

Sobór Watykański II w swoim nauczaniu, dowartościowującym świeckich, głosi prawdę o właściwym im powołaniu:

„Natomiast zadaniem ludzi świeckich, z tytułu właściwego im powołania jest szukać Królestwa Bożego, zajmując się sprawami świeckimi i kierując nimi po myśli Bożej. Żyją oni w świecie, to znaczy pośród wszystkich razem i poszczególnych spraw i obowiązków świata i w zwyczajnych warunkach życia rodzinnego i społecznego, z których niejako utkana jest ich egzystencja. Tam ich Bóg powołuje..."2

Nauczanie Soboru o świeckim powołaniu laików podejmuje i rozwija VII Synod Biskupów. W kontekście wymownej przypowieści Chrystusa o zapro-

\footnotetext{
${ }^{1}$ Papież J a n P a w el I I, Posynodalna adhortacja apostolska: Christifideles laici, 30 XII 1988, Libreria Editrice Vaticana 1989, tekst polski (= adhortacja Ch. L.), n. 34.

${ }^{2}$ Konstytucja soborowa Lumen gentium, n. 31, 2.
} 
szonych do pracy w winnicy ukazuje role i zadania świeckich we współczesnym świecie.

Obraz świata, przedstawiony przez adhortację Christifideles laici, jest dramatyczny i ponury, a nawet tragiczny. Swiat jest rozdarty nienawiścią, wojnami, podziałami; wstrząsany rewolucjami; gnębiony zbrojeniami, zwłaszcza nuklearnymi; nękany terroryzmem. Tyle na nim nieszczęść, kataklizmów, krzywd, niesprawiedliwości; tylu ludzi głodnych, torturowanych, bezprawnie więzionych czy osadzonych w obozach i prześladowanych. W tej dramatycznej godzinie historii świata i ludzkości istnieje wiele przeciwieństw: zło walczy z dobrem, niesprawiedliwość ze sprawiedliwością, nienawiść z miłością, bezsens z nadzieją, przemoc z wolnością. Swiat jawi się jako ogromne zachwaszczone pole, na którym szerzy się uporczywie zobojętnienie religijne, ateizm, zeświecczenie, sekularyzm. Człowiek odurzony swoimi zdobyczami naukowotechnicznymi, a zwłaszcza zafascynowany najdawniejszą, ale wciąż aktualną pokusą zrównania się z Bogiem, zapomina o Bogu, odrzuca Go, a na Jego miejsce stawia różne idole, którym służy ${ }^{3}$.

Groźny obraz współczesnego świata ukazany w adhortacji Christifideles laici jest koherentny z nauczaniem encykliki Sollicitudo rei socialis z 30 XII 1987 r. Tam także papież kreśli panoramę współczesnego świata, która nie napawa radością i optymizmem, lecz wprost przeciwnie grozą i niepokojem. Papież pisze o niezliczonej rzeszy mężczyzn i kobiet, dzieci, dorosłych i starców, którzy cierpią nieznośną nędzę. Nędza ta współistnieje z wystawnym bogactwem. Encyklika wspomina o różnych formach ucisku i wyzysku ekonomicznego, politycznego i religijnego. Potępia przejawy rasizmu, jak również różne formy imperializmu i neokolonializmu. Występuje przeciw wyścigowi zbrojeń i podziałowi na bloki militarne. Nawołuje do solidarnego i sprawiedliwego rozwiązania problemu zadłużenia ${ }^{4}$.

Aktualne oblicze świata ukazane zarówno w adhortacji Christifideles laici, jak i encyklice Sollicitudo rei socialis, nie jest beznadziejne. Rozdarty świat pragnie pokoju, jedności, zgody, sprawiedliwości i miłości. Zniewolony człowiek tęskni za poszanowaniem swej godności, za możliwością rozwoju i prawdziwego postępu, a w zagrożonej niewiarą duszy ludzkiej nic nie zdołało zniweczyć pragnienia i potrzeby religii. W tej sytuacji staje się jasne, że VII Synod Biskupów porównuje świat do winnicy z przypowieści Chrystusa: „Ewangeliczna przypowieść ukazuje naszym oczom rozległą winnicę Pańską oraz rzeszę ludzi, mężczyzn i kobiet wezwanych przez Boga i wysłanych tam do pracy. Winnicą jest cały świat, który winien zostać przemieniony zgodnie z Bożym planem w perspektywie ostatecznego przyjścia Królestwa Bożego"5.

\footnotetext{
${ }^{3}$ Por. adhortacja Ch. L., n. $4-6$.

${ }^{4}$ Por. encyklika Sollicitudo rei socialis, Watykan 1988, wyd. polskie, n. $11-26$.

${ }^{5}$ Adhortacja Ch. L., n. 1.
} 
Ewangeliczna winnica - świat wymaga gruntownej odnowy. Do tej pracy wzywa Chrystus słowami: „Idźcie i wy do mojej winnicy” (Mt 20,3-4). Wezwanie to dotyczy nie tylko biskupów, kapłanów, zakonników i zakonnic, lecz także świeckich. Można powiedzieć, że do odnowy świata - winnicy wzywa Chrystus przede wszystkim świeckich ${ }^{6}$. Wezwanie to ma charakter osobisty. Adhortacja Christifideles laici podkreśla niepowtarzalność i indywidualny charakter każdego powołania: „To mnie Bóg wzywa, mnie posyła do pracy w swojej winnicy; mnie wzywa i posyła, abym pracował dla przyjścia Jego królestwa w dziejach... W istocie odwiecznie byliśmy obecni w Bożym zamyśle i odwiecznie umiłował nas jako osoby jedyne i niepowtarzalne, wzywając każdego z nas jego własnym imieniem, jak dobry Pasterz, który woła swoje owce po imieniu (J 10,3)"?.

W swoim odwiecznym planie Bóg wyznaczył każdemu program działania. Ten program człowiek poznaje i uznaje przez wiarę, podejmuje z miłością i realizuje natchniony nadzieją. Na osobiste wezwanie potrzebna jest osobista odpowiedź: „Wszak Bóg w Jezusie Chrystusie każdego wzywa jego własnym imieniem, jego wezwanie 'idźcie i wy do mojej winnicy' zwrócone jest do każdego osobiście i brzmi: 'pójdź i ty do mojej winnicy' "8.

Wezwanie Chrystusa do odnowy świata przez głoszenie Ewangelii — do czego wezwany jest osobiście każdy świecki - jest dzisiaj szczególnie natarczywe i ponaglające: „Z pewnością nakaz Jezusa: 'Idźcie i głoście Ewangelię' zawsze pozostaje tak samo ważny i przynaglający. Jednak sytuacja aktualna nie tylko świata, ale także różnych części Kościoła absolutnie wymaga, aby na słowa Chrystusa odpowiedzieć posłuszeństwem bardziej zdecydowanym i wielkodusznym. Każdy uczeń jest wezwany osobiście, nikomu nie wolno uchylać się od osobistej odpowiedzi"9. Natarczywość wezwania Chrystusowego jest uzasadniona trudną sytuacją religijną świata ${ }^{10}$. Osobista więc odpowiedź winna być dana wielkodusznie oraz zrealizowana z jak największą gorliwością i miłością. W tym celu potrzebna jest formacja. Świecki — dając odpowiedź na wezwanie i powołanie Boże - potrzebuje permanentnej formacji, ustawicznego wychowywania. Za formację świeckich odpowiedzialni są wszyscy, a więc pasterze i sami świeccy, w Kościele bowiem „dobro wszystkich staje się dobrem każdego, a dobro każdego staje się dobrem wszystkich"11.

Powołanie świeckich, zgodnie z nauczaniem Chrystusa, ma być dynamiczne, ma nieustannie rozwijać się i wzrastać oraz przynosić coraz więcej owoców: „Każdą latorośl, która we mnie nie przynosi owocu, odcina, a każdą, która

${ }^{6}$ Por. adhortacja Ch. L., n. 2.

7 Tamże, n. 58.

${ }^{8}$ Tamże, n. 28.

${ }^{9}$ Tamże, n. 33 .

10 Por. D. del Rio, Riciristianizzare la societa umana, [w:] Ecclesia, studi, ricerche, documenti de vita ecclesiale, pod red. M. U baldi, Roma 1989, s. 46- 48 .

${ }^{11}$ Adhortacja Ch. L., n. 28. 
przynosi owoc oczyszcza, aby przynosiła owoc obfitszy" (J 15, 1-2). Warunkiem tego jest ustawiczna formacja duchowości świeckich. Ojcowie synodalni w następujący sposób określili formację: „Stały proces osobistego dojrzewania i upodabniania się do Chrystusa, zgodnie z wolą Ojca pod kierunkiem Ducha Świętego"12. Rozwój powołania i należyta formacja wymaga od świeckich wsłuchiwania się w Słowo Boże i w nauczanie Kościoła, wymaga korzystania z sakramentów świętych, zwłaszcza pokuty i Eucharystii oraz z kierownictwa duchowego. Nie ma rozwoju duchowego bez modlitwy, bez czynnego udziału w liturgii, bez praktykowania cnót. Do tego siłę i laskę daje Bóg, który jest pierwszym wychowawcą swojego ludu ${ }^{13}$.

Bóg-wychowawca powołuje wszystkich do życia świętego, do doskonałej miłości. Powołanie do świętości jest niewyzbywalnym wymogiem tajemnicy Kościoła, który jest Mistycznym Ciałem Chrystusa. Jego głową jest Chrystus, a jego członkowie mają udział w świętości Głowy. Powołanie do świętości wyrasta z chrztu i odnawia sią w innych sakramentach, zwłaszcza w Eucharystii. Źródłem świętości jest Chrystus, a kto trwa w Nim „ten przynosi owoc obfity” $(\mathrm{J} 15,5)^{14}$.

W powołaniu zatem świeckich decydujące znaczenie posiada łaska, zresztą samo powołanie jest łaską. Człowiek świecki otrzymuje łaskę od Boga, aby na nowo ukształtować swoje życie zgodnie z Ewangelią, aby nadać nową wartość swojej świeckiej egzystencji. Pełna odpowiedź domaga się konkretnego życia $\mathrm{z}$ wiary, natchnionego miłością i nadzieją oraz przezwyciężenia rozłamu między wiarą a życiem codziennym ${ }^{15}$.

Swieccy są powołani do świętości na równych i pełnych prawach z innymi uczniami Chrystusa. Lecz powołanie to posiada swoją specyfikę wynikającą z ich świeckiego charakteru: „Właściwością specyficzną laików jest ich charakter świecki... Szczególnym więc ich zadaniem jest tak rozświetlać wszystkie sprawy doczesne, z którymi ściśle są związani, i tak nimi kierować, aby się ustawicznie dokonywały i rozwijały po myśli Chrystusa, i aby służyły chwale Stworzyciela i Odkupiciela"16. Swieckość zatem polega na ścisłym powiązaniu laików z rzeczywistością ziemską i kształtowaniu jej zgodnie z Ewangelią. Mówiąc inaczej, wierni świeccy inspirowani duchem ewangelicznym, wykonując właściwe sobie świeckie zadania, przyczyniają się do przemiany, odnowy i uświęcenia świata oraz jego urządzeń „na kształt zaczynu, od wewnątrz niejako, i w ten sposób przykładem zwłaszcza swego życia promieniując wiarą, na-

12 Tamże, n. 57.

13 Por. tamże, n. 61.

${ }^{14}$ Por. tamże, n. $16-17$.

15 Por. M. D. Ch enu, Lud Boży w świecie, Kraków 1968, s. 76-77; por. R. S o ba ński, Kościót - prawo - zbawienie, Katowice 1979, s. 102 - 105; por. R. B ul t o t, Teologia rzeczywistości ziemskich a duchowość laikatu, „Concilium” 1-10 (1966/7), Poznań - Warszawa 1969, s. 523.

${ }^{16}$ Konstytucja soborowa Lumen gentium, n. 31. 
dzieją i miłością, ukazują innym Chrystusa"17. Przez świadectwo swojego życia świeccy, uświęcając świat, są w nim obecni na sposób ziarna, które rozwija się i przynosi plon ${ }^{18}$.

Tak pojęta świeckość różni się od zeświecczenia i sekularyzmu oraz stanowi wielkie dobro Kościoła ${ }^{19}$. Kościół posiada autentyczny wymiar świecki, wynikający z jego natury i misji. Kościół, choć nie jest ze świata, lecz żyje w świecie i w nim prowadzi odkupieńcze dzieło Jezusa Chrystusa, mające na celu zbawienie ludzi i odnowę porządku doczesnego. W świeckim wymiarze Kościoła uczestniczą w szczególniejszy sposób wierni świeccy, oni bowiem stanowią Kościół i w nim mają dokonać uświęcenia i odnowy świata, w którym żyją, pracują, uczą się, wypoczywają, utrzymują ze sobą różnorodne kontakty: przyjacielskie, społeczne, zawodowe, kulturalne itd. W ten sposób świat staje się polem i narzędziem świeckich w realizacji ich właściwego powołania, które winno się urzeczywistniać w świecie, niejako wewnątrz świata i jego spraw, kształtowanych i urządzanych zgodnie z Ewangeliąa ${ }^{20}$.

W konsekwencji fakt bycia i działania w świecie posiada dla świeckich znaczenie nie tylko antropologiczne i socjologiczne ale przede wszystkim teologiczne i kościelne: „Swiecki charakter laikatu jest pojęciem o znaczeniu nie tylko socjologicznym, ale przede wszystkich teologicznym. Można go zrozumieć tylko w świetle stwórczego i odkupieńczego aktu Boga, który powierzył świat ludziom, aby uczestniczyli w dziele stworzenia, wyzwalali je spod działania grzechu i by sami dążyli do świętości poprzez małżeństwo, wybór celibatu, życie rodzinne, zawodowe a także wielorakie formy działalności społecznej"21. Tak realizowane powołanie świeckich przyczynia się do wzrostu świętości Kościoła i do uświęcania świata.

Świętość Kościoła, będąca źródłem i miarą jego dynamizmu, ujawnia się w obrębie różnych stanów życia i rozmaitych w nim powołań. W stanie życia świeckiego istnieją różne powołania, czyli różne drogi duchowe i apostolskie poszczególnych wiernych świeckich. Z $\mathrm{Z}$ pnia powszechnego powołania świeckich niejako wyrastają powołania specyficzne, będące wyrazem jedności i różnorodności Kościoła ${ }^{22}$.

Kościół Chrystusowy za pośrednictwem świeckich ma być obecny w świecie jako znak i źródło nadziei. Rozdartemu światu Kościół poprzez świeckich wi-

${ }^{17}$ Tamże, n. 31.

18 Por. J. B e y e r, Laicat ou peuple de Dieu, [w:] Atti del Congresso Internazionale di Diritto Canonico, Milano 1972, s. 240-241.

${ }_{19}$ Por. J a n P a weł I I, List do kaptanów na Wielki Czwartek, Watykan 1989, n. 5.

${ }^{20}$ Por. adhortacja Ch. L., n. 15.

21 Tamże, n. 15.

22 Por. tamże, n. $55-56$. 
nien głosić orędzie pokoju i miłości. Świeccy zatem są powołani, aby w Kościele i przez Kościół służyć społeczeństwu, a ich troska o społeczeństwo wyrażać się powinna przede wszystkim troską o człowieka i o jego godność.

\section{Obrona godności ludzkiej}

Kościół-wspólnota ewangelizowana i ewangelizująca jest sługą ludzi, a świeccy uczestniczą w misji służenia człowiekowi i społeczeństwu. Ostatecznym celem Kościoła jest budowanie Królestwa Bożego, które staje się źródłem pełnego wyzwolenia i zbawienia ludzi. Stąd Kościół objawia światu tajemnicę Boga jaśniejącego w Jezusie Chrystusie oraz objawia człowieka jemu samemu, ukazując mu całą prawdę o tym, kim jest $\mathrm{i}$ jakie jest jego przeznaczenie. W tej optyce jawi się wyraziście wezwanie Kościoła do służenia człowiekowi. Misja służby człowiekowi najgłębiej wyrasta z faktu, że Syn Boży przez swoje Wcielenie zjednoczył się jakoś z każdym człowiekiem. Dlatego człowiek jest pierwszą i podstawową drogą Kościoła w wypełnianiu Jego posłannictwa ${ }^{23}$.

W nauczaniu Kościoła wielokrotnie występuje troska o godność człowieka: „Kościół idąc ku swemu własnemu zbawczemu celowi, nie tylko daje człowiekowi uczestnictwo w życiu Bożym, lecz także rozsiewa na całym świecie niejako odbite światło Boże zwłaszcza przez to, że leczy i podnosi godność osoby ludzkiej, umacnia więź społeczeństwa ludzkiego oraz wlewa głębszy sens i znaczenie w powszednią aktywność ludzi"24.

Godność osoby ludzkiej we współczesnym świecie jest zagrożona i narażona na działanie przemocy, wskutek której jest ona poddana różnym zniewoleniom i niejednokrotnie dostaje się w niewolę silniejszego. Silniejszy może mieć, jak mówi adhortacja Christifideles laici, różne imiona. Są to: ideologia, władza ekonomiczna, nieludzki system polityczny, technokracja, agresywność środków przekazu, niesprawiedliwe prawodawstwa ${ }^{25}$. W tej sytuacji uświadomienie sobie i innym nienaruszalnej godności każdej osoby ludzkiej stanowi istotne zadanie posługi na rzecz rodziny ludzkiej, do której sprawowania jest powołany Kościól, a w nim katolicy świeccy. Winni oni zadbać, aby prawodawstwa stanowione miały za cel ochronę godności osoby ludzkiej26.

Godność ta jest najcenniejszym dobrem człowieka, który dzięki niej przewyższa swoją wartością cały świat materialny, gdyż tylko człowiek jest osobą oraz stanowi ośrodek i szczyt stworzenia. Godność osoby ludzkiej jawi się w całym pięknie i wartości wówczas, gdy „weźmie się pod uwagę jej pochodzenie i przeznaczenie: stworzony przez Boga na jego obraz i podobieństwo, odkupio-

${ }^{23}$ Por. tamże, n. 36.

${ }^{24}$ Konstytucja soborowa Gaudium et spes, n. 40.

25 Por. adhortacja Ch. L., n. 5.

26 Por. adhortacja Ch. L., n. 37; por. A. Mart in i, Il diritto nella realta umana, [w:] Il diritto nel mistero della Chiesa, Roma 1986, s. 10-11. 
ny drogocenną krwią Chrystusa, człowiek został wezwany do tego, by być synem w Synu, żywą świątynią Ducha Świętego i jest przeznaczony do życia wiecznego w uświęcającej komunii z Bogiem" 27. Zatem początki człowieka nie sięgają ani jego własnej działalności jednostkowej, ani zbiorowej, lecz daru Boga Stwórcy. Dar ten ma podwójny wymiar — naturalny i nadnaturalny. Człowiek stworzony przez Boga jest przedmiotem Jego nieskończonej i wiernej miłości. Jej szczególnym przejawem jest dzieło Odkupienia, dokonane przez Jezusa Chrystusa, zajmujące centralne miejsce w historii zbawienia. Przez swoją Mękę, Śmierć i Zmartwychwstanie Chrystus Odkupiciel udziela ludziom łaski, siły miłości do uczestnictwa w życiu Bożym i wiecznego zbawie$\mathrm{nia}^{28}$.

Osobista godność stanowi podstawę równości wszystkich ludzi, gdyż wszyscy posiadają tę samą ludzką naturę. We wspólnocie Kościoła równość ta otrzymuje nowy wymiar, o którym naucza Sobór Watykański II: „Jeden tedy jest Lud Boży wybrany: jeden Pan, jedna wiara, jeden chrzest (Ef 4,5); wspólna jest godność członków wynikająca z ich odrodzenia w Chrystusie, wspólna łaska synów, wspólne powołanie do doskonałości, jedno zbawienie, jedna nadzieja i miłość niepodzielna"29. Fundamentalna równość wszystkich ochrzczonych jest zagwarantowana w Kodeksie prawa kanonicznego z 1983 r.: „Z racji odrodzenia w Chrystusie wszyscy wierni są równi co do godności i działania, na skutek czego każdy, zgodnie z własną pozycją i zadaniem współpracuje w budowaniu Ciała Chrystusowego" (kan. 208).

Podstawowa równość wszystkich ludzi wyklucza jakąkolwiek dyskryminację: rasową, religijną, ekonomiczną, społeczną, polityczną, kulturową i etniczną. Każda dyskryminacja jest niesprawiedliwością i hańbą, naruszającą godność osoby i to nie tylko tej, która staje się ofiarą niesprawiedliwości, ale jeszcze bardziej tej, która ją powoduje ${ }^{30}$. Toteż wierni świeccy, pamiętając o równości panującej między nimi, są zobowiązani eliminować wszelkie przejawy dyskryminacji spośród siebie, jak i z życia społecznego oraz szanować słuszną wolność innych ${ }^{31}$.

Godność osobista jest źródłem współuczestnictwa i solidarności między ludźmi. Warto odwołać się do nauczania o solidarności zawartego w encyklice Sollicitudo rei socialis papieża Jana Pawła II. Solidarność pomaga dostrzec

${ }^{27}$ Adhortacja Ch. L., n. 37.

${ }^{28}$ Kongregacja Doktryna Wiary, Instrukcja Libertatis nuntius, Rzym 1985, rozdział I 2; por. Międzynarodowa Komisja Teologiczna, Godnośc prawa osoby ludzkiej; tłumaczenie w: „Chrześcijanin w świecie” 17 : $1985 \mathrm{nr} 18$ s. 88; por. J. D y d u c h, Gtoszenie praw ludzkich w instrukcjach na temat chrześcijańskiego wyzwolenia, „Notificationes” $124: 1986$ s. 103.

${ }^{29}$ Konstytucja soborowa Lumen gentium, n. 32, 2.

30 Por. adhortacja Ch. L., n. 37.

${ }^{31}$ Por. S. P a s t e r n a k, Zagadnienie niedyskryminacji w dokumentach soboru watykańskiego II, „Prawo Kanoniczne” 17: $1974 \mathrm{nr} 1-2$ s. 199-201; por. W. A y m a n s, Munus und sacra potestas, [w:] Akten des IV Internationalen Kongresses für Kirchenrecht, red. E. Corecco, Freiburg 1981 , s. $199-201$. 
drugiego - osobę, lud czy naród — nie jako przedmiot czy narzędzie, ale jako „podobnego nam”. W świetle wiary solidarność sprawia, że bliźni jawi się „,nie tylko istotą ludzką z jej prawami i podstawową równością wobec wszystkich, ale staje się żywym obrazem Boga-Ojca, odkupionym krwią Jezusa Chrystusa i poddanym stałemu działaniu Ducha Swiętego. Winien być przeto kochanym, nawet jeśli jest wrogiem, tą samą miłością, jaką miłuje go Bóg"32.

Uznanie godności człowieka prowadzi do poszanowania praw ludzkich, ich obrony, głoszenia i popierania. Praw tych nie może zmienić, ani znieść żadna jednostka, czy grupa, władza lub państwo, gdyż dawcą ich jest sam Bóg ${ }^{33}$. Posynodalna adhortacja nie stanowi katalogu praw czlowieka, wymienia tylko niektóre z nich. Na pierwszym miejscu wylicza prawo do życia, przysługujące każdej osobie ludzkiej od chwili poczęcia aż do naturalnej śmierci, we wszystkich fazach jej rozwoju i we wszelkich warunkach, a więc niezależnie od tego czy jest zdrowa czy chora, w pełni sprawna czy upośledzona, bogata czy biedna. Prawa do życia mają bronić wszyscy, ale szczególne zadania spoczywają tu na niektórych świeckich: rodzicach, wychowawcach, pracownikach służby zdrowia, oraz osobach sprawujących władzę gospodarczą i polityczną ${ }^{34}$.

Synod opowiada się za życiem, dostrzegając jego wspaniałość i broni je przed tymi, którzy na nie czyhają. Potępia również to wszystko, co godzi w samo życie: jak wszelkiego rodzaju zabójstwa, ludobójstwa, spędzanie płodu, eutanazję i dobrowolne samobójstwa; wszystko, cokolwiek narusza integralność osoby ludzkiej, jak okaleczenia i tortury zadawane ciału i duszy, wszystko co ubliża godności ludzkiej, jak nieludzkie warunki życia, bezpodstawne aresztowania, deportacje, niewolnictwo, prostytucję, handel kobietami i młodzieżą a także nieludzkie warunki pracy ${ }^{35}$.

Papież w adhortacji Christifideles laici, nawiązując do instrukcji $O$ szacunku dla rodzącego się życia ludzkiego i o godności jego przekazywania, nawołuje do poszanowania nietykalności godności osobistej człowieka od pierwszej chwili jego istnienia. Ma to miejsce wówczas, kiedy nauka i technika przy pomocy godziwych środków angażują się w obronę życia i leczenie chorób poczynając od najwcześniejszych stadiów istnienia płodu; odrzucając zaś wszelkie manipulacje w zakresie genetyki godzące w prawa ludzkie i w biologiczną istotę rodzaju ludzkiego. Świeccy zaangażowani w różne dziedziny pracy naukowej, techniki, medycyny, działalności prawodawczej i gospodarczej, są zobowiązani podejmować wymagania stawiane przez nowe problemy bioetyki ${ }^{36}$. Taka postawa Urzędu Nauczycielskiego Kościoła, ukazująca autentyczną

32 N. 40.

33 Por. adhortacja Ch. L., n. 38.

34 Por. tamże, n. 38.

35 Konstytucja soborowa Gaudium et spes, n. 27; adhortacja Ch. L., n. 38.

36 Por. adhortacja Ch. L., n. 38; por. Kongregacja Doktryny Wiary, Instrukcja Donum vitae, 22 II 1987, AAS $80: 1988$ s. $70-102$. 
wolę Boga zawartą w prawie natury i Objawieniu, kieruje się miłością do człowieka i pomaga mu w rozpoznaniu i realizowaniu jego praw i obowiązków ${ }^{37}$.

Poszanowanie godności osobistej wymaga uznania religijnego wymiaru człowieka. Z tego wypływa poszanowanie prawa do wolności sumienia i wolności religijnej. Wolność religijna leży u podstaw wszystkich praw ludzkich. Synod, stwierdzając istnienie w świecie dyskryminacji i prześladowań religijnych, zadawanych cierpień a nawet śmierci za wyznawanie religii, staje w obronie prześladowanych i pragnie podziękować tym katolikom świeckim, którzy żyją jako niestrudzeni świadkowie wiary, trwając niezłomnie w jedności ze Stolicą Apostolską, mimo ograniczania ich wolności i pozbawiania posługi kapłańskiej. Często ryzykują własnym życiem, dając w ten sposób świadectwo swojej wierze i Kościołowi ${ }^{38}$.

Spośród innych praw ludzkich Synod głosi wolność zrzeszania się świeckich w Kościele: „Sprawą pierwszej wagi jest uznanie wolności zrzeszania się świeckich w Kościele. Wolność ta jest autentycznym prawem, które nie jest jakiegoś rodzaju ustępstwem ze strony władzy, ale wywodzi się ze chrztu, jako z sakramentu, który wzywa świeckich do aktywnego udziału w komunii i misji Kościoła"39. W realizowaniu tego prawa świeccy muszą pamiętać, że tworzone przez nich zrzeszenia winny być prawidłowo zakorzenione we wspólnocie Kościoła. Stąd potrzeba więzi stowarzyszeń świeckich z hierarchią kościelną ${ }^{40}$. Prawo wolności stowarzyszania się posiada swoje najgłębsze uzasadnienie w społecznej naturze czlowieka, osoba ludzka posiada bowiem naturalny i strukturalny wymiar społeczny.

Podstawowym i pierwszym przejawem społecznego wymiaru osoby jest małżeństwo i rodzina. Rodzina jest kolebką życia i miłości, gdzie człowiek rodzi się i wzrasta, jest pierwszym miejscem humanizacji osoby i społeczeństwa. Rodzina jednak współcześnie jest zagrożona przez ludzki egoizm, kampanie antyprokreacyjne, politykę totalitarną; przez nędzę i ubóstwo materialne, kulturalne i moralne; jak również przez mentalność hedonistyczną i konsumpcyjną ${ }^{41}$. W tej sytuacji zadaniem świeckich jest bronić wartości rodziny i budzić wrażliwość na jej potrzeby. Mają oni zadbać o to, by rodzina była świadoma własnej tożsamości i tego, że jest podstawową komórką społeczną a także, aby ona sama stawała się coraz bardziej aktywnym promotorem swego rozwoju i uczestnictwa w życiu społecznym oraz w życiu narodu ${ }^{42}$.

${ }^{37}$ Por. J. Kow a ls k i, Obrona życia ludzkiego w praktyce lekarskiej w świetle nauki Kościoła, „Chrześcijanin w świecie” 18:1986 nr. 8-9 s. 76-95.

${ }^{38}$ Adhortacja Ch. L., n. 39.

${ }^{39}$ Tamże, n. 29.

${ }^{40}$ Por. K. Wo j t y ł a, U podstaw odnowy, Kraków 1972, s. 387; por. R. B a c c a ri, Il diritto di associazione, dei laici nell ordinamento canonico, „Monitor Ecclesiasticus” 107: 1982 s. 551 - 572 .

${ }^{41}$ Por. adhortacja Ch. L., n. 40.

42 Por. tamże, n. 40. 
Trwałość narodu, jego przyszłość zależy w pierwszym rzędzie od rodziny. Poszanowanie praw rodziny i osoby wiąże się ściśle z poszanowaniem praw narodów. Adhortacja nawiązuje w tym względzie do nauczania encykliki Redemptor hominis i stwierdza, że naruszanie praw człowieka i rodziny idzie w parze $\mathrm{z}$ gwałceniem praw narodów ${ }^{43}$.

VII synod biskupów, podejmując problem poszanowania osoby ludzkiej, poświęcił wiele uwagi sytuacji i roli kobiety, podkreślając jej wkład w rozwój społeczeństwa i odnowę świata. Uznanie osobowej godności kobiety wymaga zapewnienia jej pełnego uczestnictwa zarówno w życiu Kościoła, jak i w życiu publicznym i społecznym. Zadaniem Kościoła jest wyrażenie sprzeciwu wobec wszystkich form dyskryminacji i pogwałcenia godności kobiety oraz uznanie wszystkich talentów kobiet i mężczyzn oraz zastosowanie ich w praktyce. Warunkiem zapewnienia kobiecie należnego jej miejsca w Kościele i społeczeństwie jest podjęcie dokładnych studiów nad podstawami antropologicznymi i teologicznymi statusu mężczyzny i kobiety, celem sprecyzowania tożsamości właściwej kobiecie w relacji odmienności i wzajemnej komplementarności w odniesieniu do mężczyzny. Ta refleksja została przeprowadzona w Liście apostolskim Mulieris dignitatem, będącym także owocem VII synodu biskupów, zaś adhortacja Christifideles laici podaje wskazania duszpasterskie: „Rzeczą absolutnie konieczną jest przejście od teoretycznego uznania aktywnej i odpowiedzialnej obecności kobiety w Kościele do praktycznej realizacji. Takie właśnie znaczenie posiada niniejsza adhortacja, która zwracając się do świeckich katolików, celowo i wielokrotnie precyzuje, że chodzi o mężczyzn i kobiety"43a.

VII synod biskupów, analizując sytuację współczesnego świata, dostrzeg1 palący problem naruszania godności osoby ludzkiej i gwałcenia jej podstawowych praw. Dlatego stanął w obronie człowieka i tych jego praw, które dziś są najbardziej zagrożone. Troska o godność człowieka o jego prawa jest głównie zadaniem katolików świeckich, którzy mają dawać przykład poszanowania praw człowieka, mają je głosić, a w razie potrzeby bronić. Obrona człowieka, rodziny i narodu jest ważnym elementem zaangażowania świeckich w odnowę porządku rzeczy doczesnych.

\section{Odnowa porzadku doczesnego}

Porządek doczesny, świat jest miejscem, w którym Kościół spełnia swoją misję. Zgodnie z zamysłem Chrystusa, Kościół jest powołany do miłowania

${ }^{43}$ Por. tamże, n. 39; por. encyklika Redemptor hominis, n. 17: AAS 71 : 1979 s. $297-298$.

43a Adhortacja Ch. L., n. 51. 
świata i służenia mu przez niesienie łaski Bożej. Dzięki niej ludzie zdolni są odrodzić świat, uwolnić siebie i porządek doczesny od grzechu i uporządkować całą rzeczywistość według myśli Bożej. Kościół jest posłany do świata, aby żyjąc w świecie, lecz nie będąc światem - był solą i zaczynem tajemnicy Odkupienia, która zbawia świat uwalniając go z niewoli grzechów i przywracając wolność dzieci Bożych. W ten sposób lud zbawionych staje się ludem zbawiającym $^{44}$.

Odnowa porządku doczesnego, kształtowanie spraw doczesnych według zamysłu Stworzyciela, zgodnie z Ewangelią, jak naucza sobór watykański II, została powierzona wiernym świeckim: „Swieccy zaś powinni podjąć trud odnowy porządku doczesnego jako własne zadanie i spełniać bezpośrednio i zdecydowanie, kierując się światłem Ewangelii i duchem Kościoła, przynagleni miłością chrześcijańską. Jako obywatele powinni współpracować ze współobywatelami, działając z właściwą kompetencją i na własną odpowiedzialność, szukając wszędzie i we wszystkim sprawiedliwości Królestwa Bożego"45.

Odnowa porządku doczesnego nie jest możliwa bez nowej ewangelizacji. Wiele krajów i narodów, niegdyś promieniujących życiem chrześcijańskim i religijnością, ulegają dziś zobojętnieniu, sekularyzmowi, ateizmowi i żyją tak, jak gdyby Bóg nie istniał. Narodom tym potrzebna jest nowa ewangelizacja, zapewniająca rozkwit czystej i głębokiej wiary. W owym zadaniu ludzie świeccy, na mocy swego uczestnictwa w prorockim urzędzie Chrystusa, biorą pełny udział: „Do nich w szczególności należy świadczenie o tym, jak wiara chrześcijańska daje jedyną pewną odpowiedź, którą wszyscy mniej lub bardziej świadomie przyjmują i pragną, na problemy i nadzieje, jakie życie stawia przed każdym człowiekiem i każdym społeczeństwem"46. Warunkiem spełnienia przez świeckich tego zadania jest przezwyciężenie rozłamu między Ewangelią a życiem osobistym, rodzinnym i społecznym, jest synteza Ewangelii i życia codziennego. Mówiąc inaczej, chodzi o świadectwo życia i świadectwo słowa, które wierni świeccy winni dawać w tych środowiskach, w których żyją, pracują i wypoczywają. Chodzi także o dotarcie do tych i podjęcie wobec nich zadań misyjnych, którzy przestali wierzyć lub nie żyją według wiary otrzymanej na chrzcie świętym ${ }^{47}$.

Z nową ewangelizacją winni świeccy zwrócić się także do tych, którzy do tej pory nie znają Chrystusa Odkupiciela człowieka. Tam mają wspólnie z innymi misjonarzami przyczyniać się do zakorzenienia Kościoła, do formacji dojrzałego i odpowiedzialnego laikatu ${ }^{48}$.

${ }^{44}$ Por. G. Lazza ti, Świeccy a chrześcijańskie zaangażowanie w sprawy doczesne, Warszawa 1988 , s. $57-59$.

${ }_{45}$ Dekret soborowy Apostolicam actuositatem, n. 7, 5.

${ }^{46}$ Adhortacja Ch. L., n. 34.

${ }^{47}$ Por. tamże, n. 34.

48 Por. tamże, n. 35. 
Służba społeczeństwu przybiera różne formy pomocy charytatywnej, którą Kościól, głównie poprzez świeckich, pełnił od zarania swego istnienia, uważając się za powołanego do służby miłości. Miłość bowiem ożywia i wspiera czynną solidarność, uwrażliwioną na różnorodne potrzeby człowieka. Miłość bliźniego, wyrażająca się w dziełach miłosierdzia, stanowi najbardziej bezpośrednią i powszechną formę odnowy porządku doczesnego ${ }^{49}$.

Miłość okazywana i służąca osobie jest ściśle powiązana ze sprawiedliwością. Jedna i druga winna być podstawą wszelkiej działalności politycznej i społecznej. Bez nich niemożliwa jest odnowa życia politycznego. Polityka we współczesnym świecie została głęboko zraniona egoizmem, korupcją, karierowiczostwem i kultem władzy. Dlatego wymagają gruntowej odnowy, której winni dokonać ludzie świeccy, którzy nie mogą uchylić się od udziału w działalności politycznej. Podstawowym kryterium polityki jest dążenie do wspólnego dobra jako dobra wszystkich ludzi i całego człowieka. Dobro zaś wspólne obejmuje sumę tych warunków życia społecznego, dzięki którym jednostki, rodziny i zrzeszenia mogą pełniej i łatwiej osiągnąć własną doskonałośćs0.

Wyznacznikiem i namiarem działalności politycznej winna być obrona i promocja sprawiedliwości rozumianej jako cnota i siła moralna. Podstawą sprawowania władzy politycznej ma być służba wobec wspólnoty politycznej, połączona z wymaganą kompetencją i skutecznością działania. Narzędziem polityki zmierzającej do prawdziwego rozwoju człowieka jest solidarność, sprawiająca czynne i odpowiedzialne uczestnictwo w życiu politycznym wszystkich obywateli oraz rozmaitych grup, związków zawodowych i partii. Solidarność polityczna musi przekroczyć granice poszczególnych krajów czy bloków i objąć wszystkie kontynenty. Owocem takiej solidarnej polityki jest pokój ${ }^{51}$. Do prowadzenia tak pojętej działalności politycznej wezwani są katolicy świeccy. Winni oni szanować autonomię rzeczywistości ziemskich, doceniając właściwy stosunek między wspólnotą polityczną a Kościołem, który nie utożsamia się z żadną wspólnotą polityczną, ani nie wiąże się z żadnym systemem politycznym. Natomiast wierni świeccy zaangażowani w życie polityczne zobowiązani są dawać świadectwo tym wartościom ludzkim i ewangelicznym, które posiadają organiczny związek z działalnością polityczną: jak wolność, sprawiedliwość, solidarność, wierne i bezinteresowne oddanie sprawie dobra wspólnego, prosty styl życia, popieranie ubogich. Mają oni zdecydowanie wypowiedzieć walkę: nieuczciwości, kłamstwu, wykorzystywaniu dóbr publicznych dla wzbogacenia pewnych grup lub w celu zdobywania popleczników, stosowania niedozwolonych środków dla zdobycia, utrzymywania czy powiększenia władzy. Ze wszystkich sił mają się przeciwstawiać przemocy, wojnom, torturom,

\footnotetext{
49 Por. tamże, n. 41.

50 Por. adhortacja Ch. L., n. 42; por. konstytucja soborowa Gaudium et spes, n. 75.

51 Por. adhortacja Ch. L., n. 42.
} 
terroryzmowi, obozom koncentracyjnym, militaryzacji polityki, wyścigowi zbrojeń oraz zagrożeniu militarnemu. W swojej działalności winni się kierować społeczną nauką Kościoła i troszczyć się o silną władzę polityczną ${ }^{52}$.

Dobro wspólne państwa wymaga silnej władzy politycznej, lecz siła władzy polega nie na ucisku, terrorze i przemocy, ale przeciwnie, ma być oparta na wolności, poczuciu odpowiedzialności, strzeżeniu dobra wspólnego i praw obywatelskich wszystkich członków wspólnoty politycznej ${ }^{53}$.

Ojcowie synodalni wezwali chrześcijan do budowania sprawiedliwego ładu społecznego i międzynarodowego, do popierania rozwoju społecznego i gospodarczego. Przypomnieli zasadę o powszechnym przeznaczeniu dóbr, w służbie którego pozostaje własność prywatna. Zadaniem świeckich jest tak pokierować życiem gospodarczo-społecznym, by uszanować godność osoby ludzkiej, jej powołanie i dobro całego społeczeństwa. Człowiek bowiem jest twórcą i celem całego życia gospodarczo-społecznego. W tym kontekście trzeba na nowo podjąć rozwiązanie problemów związanych z pracą człowieka usuwając różne nadużycia. Wśród nich trzeba wymienić bezrobocie i nieuczciwość. Praca zawodowa ma stać się drogą osobistego uświęcenia ${ }^{54}$. Adhortacja podkreśla, że życie gospodarczo-społeczne nie może się kierować wyłącznie prawami ekonomicznymi, ale również prawami moralnymi. Prawa te obowiązują także w korzystaniu z dóbr tego świata nakazując poszanowanie i ochronę środowiska naturalnego, które należy traktować rozumnie i z miłością 55 . Urząd Nauczycielski Kościoła niestrudzenie głosi zasady moralne, które winny kształtować porządek gospodarczo-społeczny, mając na uwadze troskę o człowieka, o jego prawa i zbawienie; podkreślając, że podstawą i regulatorem zdrowego ładu społecznego jest sprawiedliwość i miłość społeczna ${ }^{56}$.

Służba na rzecz osoby i społeczeństwa wyraża się i urzeczywistnia w tworzeniu i przekazywaniu kultury. Kultura jest wspólnym dobrem każdego ludu, wyrazem jego godności, wolności i twórczego zmysłu, świadectwem jego dziejowej drogi. Ewangelia odnawia życie i kulturę ludzką oraz uwalnia ją od błędów i zła, dlatego świeccy są wezwani do ewangelizowania kultury, do usuwania rozdźwięków między Ewangelią a kulturą ${ }^{57}$. Ewangelizacja kultury nie niweczy pluralizmu kulturowego, różnorodności kultur, która wynika z prawa swobodnego poszukiwania prawdy ${ }^{58}$.

52 Por. tamże, n. 42.

53 Por. B. La m be r t, Życie wspólnoty politycznej, W: Nowy obraz Kościoła, red. B. Lambert, Warszawa 1968 , s. $366-367$.

54 Por. adhortacja Ch. L., n. $42-43$.

55 Por. tamże, n. 43.

56 Por. kan. 747 KPK, 1983; por. J. Ma j k a, Etyka życia gospodarczego, Wrocław, 1982, s. 53 - 54; por. Cz. Strze s zew sk i, Chrześcijanin w życiu spotecznym i gospodarczym, „Communio" 1 : $1981 \mathrm{nr} 1-2$ s. 130.

57 Por. adhortacja Ch. L., n. 44.

58 Por. G. Lazzati, jw., s. $128-129$. 
W tworzeniu i przekazywaniu kultury szczególną rolę odgrywają środki społecznego przekazu. W ich tworzeniu i w posługiwaniu się nimi świeccy winni się kierować umiłowaniem prawdy, obroną wolności osoby i poszanowaniem jej godności, mają popierać prawdziwe wartości w kulturach poszczególnych narodów, oraz zwalczać wszelkie formy monopolizacji i manipulacji. Nie mogą zaniedbać głoszenia Ewangelii przy pomocy tych środków ${ }^{59}$.

Podejmowanie różnych działań celem odnowy porządku doczesnego to piIne zadanie świeckich. Na ich skuteczną i kompetentną interwencję oczekuje życie polityczne, społeczne, gospodarcze i szeroko pojęta kultura ludzka. W te dziedziny wkradło się wiele nadużyć, stąd nagląca potrzeba zaangażowania tam świeckich natchnionych wiarą, miłością prawdą i nadzieją.

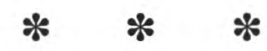

Wierni świeccy są wezwani, aby służyć społeczeństwu i światu. Swiat potrzebuje świętości świeckich, gdyż tylko w ten sposób zdołają oni odnowić porządek rzeczy doczesnych. Odczytanie powołania dokonuje się przez wiarę a jego rozwój przez pielęgnowanie życia wewnętrznego. Świecki, chcąc ludziom nieść Ewangelię, nie może być duchowo pusty, lecz ma zadbać o swoją świecką duchowość. Jej charakterystycznym rysem ma być troska o człowieka, o jego godność osobistą i prawa, a także o życie Boże w jego duszy i o jego godność chrześcijanina. W tym kontekście trzeba rozważać pozycję i zadania świeckiego - pracownika winnicy Chrystusowej i gałązkę wszczepioną w Chrystusa - Krzew Winny.

\author{
I LAICI A SERVIZIO DELLA SOCIETÁ E DEL MONDO \\ ALLA LUCE DELL'ESORTAZIONE CHRISTIFIDELES LAICI
}

Riassunto

La vocazione propria dei laici é orientata verso il mondo, che essi devono transformare e rinnovare portandovi Cristo - Il Vangelo vivo. Il rinnovamento del mondo é un compito urgente, perché esso é la vigna coperta di erbacce. Tutti i laici sono chiamati alla santitá. Essa esige da loro una continua formazione e cura della vita interiore, secondo la loro laicitá. Questa laicitá é un grande bene per la Chiesa.

I laici devono servire l'uomo nella Chiesa e attraverso la Chiesa, curandosi del rispetto della sua dignitá personale e dei suoi diritti. Bisogna in particolare sostenere e difendere questi diritti lá

${ }^{59}$ Por. adhortacja Ch. L., n. 44. 
dove sono minnacciati. Ad essi appartengono il diritto alla vita, la libertá di coscienza e la libertá religiosa. Nell'insieme del rispetto della persona umana bisogna ricordare particolarmente la libertá religiosa.

Il rinnovamento dell'ordine temporale nello spirito del Vangelo é il compito particolare dei laici. Essi devono introdurre i principi evangelici nella vita politica, sociale e culturale. Il mondo ha bisogno di una nuova evangelizzazione e di un rinnovamento delle sue strutture, che devono essere ispirate dalla fede, dalla speranza e dalla caritá. 